\title{
Cocoiculture and Society: an Integrative Review on the Biological Effects of Coconut Oil on Human Health
}

\author{
Simone Regina Alves de Freitas Barros, ${ }^{1 *}$ Ana Lídia Soares Cota, ${ }^{2}$ Rosângela Simões Gonçalves, ${ }^{3}$ Polyana Magna \\ Lima Dias, ${ }^{4}$ Rhuanna Kamilla da Silva Santos, ${ }^{5}$ Andrea Cordeiro da Silva, ${ }^{6}$ Sueli Bezerra de Melo ${ }^{7}$ \\ ${ }^{1} \mathrm{PhD}$ student in Society, Technologies and Public Policies, Tiradentes University Center, Maceió, Alagoas, Brazil \\ ${ }^{2} \mathrm{PhD}$ in Applied Dental Sciences, Professor of Dentistry, Tiradentes University Center, Maceió, Alagoas, Brazil \\ ${ }^{3}$ Master in Biotechnology in Human and Animal Health, Brazil \\ ${ }^{4}$ Specialist in Women's Health, Brazil \\ ${ }^{5}$ Residence in Obstetrics, Brazil \\ ${ }^{6}$ Specialist in Family Health Strategy, Brazil \\ ${ }^{7}$ Graduate Student in Hospital Management, Brazil
}

\section{Introduction}

The coconut tree (palm) Cocos nucifera L. is a monocot of tropical regions belonging to the Palmae family and to the subfamily Arecoideae, with solitary herbs, fibrous and robust trunks, overlapping stems and which can grow up to $25 \mathrm{~m}$ in height. Such characteristics are attributed to the coconut tree, which in turn, originates in Southeast Asia, on islands located between the Indian and Pacific oceans. It has more than 300 ecotypes and two main varieties: Typica (giant coconut tree) and Nana (dwarf coconut tree). ${ }^{1-4}$ The coconut tree is widespread in practically all continents and is distributed in more than 200 different countries, with its predominant geographic incidence between the parallels $23^{\circ} \mathrm{N}$ and $23^{\circ} \mathrm{S}$. It is considered a plant with several functionalities, considering the plurality of products that can be explored. This fact led to its recognition as a vital plant resource for all of humanity, giving it the title of the most economically important palm worldwide. ${ }^{5}$ Currently, the global area of coconut planting reaches about 12 million hectares, producing approximately 61.1 million tons. The main world producers are Indonesia, the Philippines and India, which hold $72.4 \%$ of the area and $72.5 \%$ of the world production. Brazil is in the fourth placement with only $2.6 \%$ of cultivated area, but, on the other hand, participates with $15.3 \%$ of world production. This in dex is explained by the technology used in the culture, such as the conduction and management of coconut trees, intensive cultivation systems and improved dwarf and hybrid varieties. Currently, the country has about 280 thousand hectares cultivated with coconut, distributed in almost all the national territory with production of close to two billion fruits. ${ }^{6,7}$

The coconut tree arrived in Brazil from the Cape Verde Archipelago in the 1550s and following years. It is sometimes called co co-da-bay because the state of Bahia (northeastern region) was the pioneer in Brazilian coconut culture. ${ }^{8}$ The northeastern region is the main national producer of coconut, whose position has been conquered since the introduction of the coconut tree in the country and which has been maintained, due to the favorable edaphoclimatic conditions in the coastal areas. $82.9 \%$ of Brazil's harvested coconut area and $74.0 \%$ of its production are concentrated in this region. ${ }^{7}$ The expansion of coconut palm to other regions was due to an increasing demand for coconut water and the consequent increase in its price. This generated a major change in the coconut tree culture in Brazil, from the modernization of its production process, with intensive use of inputs, technology, implementation of large projects in irrigated perimeters and use of the green dwarf
Quick Response Code:

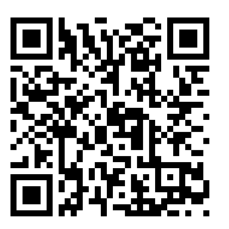

*Corresponding author: Simone Regina Alves de Freitas Barros, PhD student, Society, Technologies and Public Policies, University center, Tiradentes, Maceió, State of Alagoas, Brazil

Received: 07 November, 2020

Published: 25 January, 2021

Citation: Simone RAFB, Ana LS, Rosângela SG, Polyana MLD, Rhuanna KSS, et al. Cocoiculture and Society: an Integrative Review on the Biological Effects of Coconut Oil on Human Health. Curr Inv CIn Med Res.2021;1(1):1-8. DOI: 10.53902/CICMR.2021.01.000502 
coconut variety, expanding production and productivity by planted area. ${ }^{7,9}$ Due to the water deficit caused by the frequent droughts that occurred in the northeast region, between the years 2016 and 2017 , there was a fall in production of $11.6 \%$, a loss equivalent to 205 million fruits in just one year and 16 thousand hectares less. Crop yield in fruits/ha fell from 6.962 to $6.463(-7.2 \%) .{ }^{1,7}$

In Brazil, the crops are intended for the production of fresh dry coconut, grated coconut, coconut milk, coconut oil, dry coconut derivatives and coconut water, from green coconut. It is known that the potential for using coconut fruit is $100 \%$ and is of interest to several areas, from the energy issue, applicable to obtaining coconut biodiesel, including the use of its fiber as reinforcement in composites with viable plastic to minimize environmental and social impact, in addition to food, cosmetics and pharmacology. In addition to the mentioned uses, it still directly benefits more than 220 thousand producers, due to the large number of products obtained from industrialization. ${ }^{1,10}$

Coconut cultivation in Brazil stands out from the reality observed in many countries, not only for the economic aspects it provides, but also for the social and environmental gains from the sustainable exploitation of the culture. The advancement of techniques and adequate cultivation have enabled, especially in fragile agroecosystems such as in the Atlantic Forest and coastal areas, the insertion of small producers and a significant improvement in living conditions. ${ }^{7,11,12}$ About $90 \%$ of the world's coconut production comes from small farmers - thus defined those who work in areas of up to 5 hectares- and this production is practically consumed internally in producing countries. In Brazil, the situation is slightly different from this reality, since about $70 \%$ of the exploitation of coconut trees occurs on properties with up to $10 \mathrm{ha}^{7,13}$

The annual production value reaches $\mathrm{R} \$ 1.13$ billion and, according to the Company Brazilian Agricultural Research Corporation (Embrapa), each hectare of the crop generates an average of three direct jobs and, in turn, each direct job generates four other indirect, so that the 234 thousand hectares cultivated directly employ 700 thousand people and indirectly another 2.8 million. According to the Ministry of Agriculture, Livestock and Supply (MAPA), imports of coconut derivatives have increased substantially in recent years and have surpassed the $\$ 32$ million mark in 2016. ${ }^{7,14}$ Due to the socioeconomic importance of coconut farming in Brazil and due to the fact that new investments are promoted-capable of promoting technological advances, in 2018 the National Policy for Encouraging Quality Coconut Farming (PNICQ) was instituted through the presentation of Bill No. 10,778, which aims to increase the productivity, competitiveness and sustainability of Brazilian coconut farming. ${ }^{14}$ Given this scenario, recent studies have found that the coconut oil by-product has antibacterial, antifungal, anthelmintic activity, in addition to antiviral properties, among other health benefits. It is composed of free fatty acids (FFA), predominantly medium chain triglycerides, with $86.5 \%$ saturated, 5.8\% monounsaturated and $1.8 \%$ polyunsaturated. Of the saturated fatty acids, coconut oil is made up of $44.6 \%$ lauric acid (alsopresent in breast milk), 16.8\% myristic and $8.2 \%$ palmitic. ${ }^{15,16}$
Since the emergence of Ayurveda, which in Sanskrit means science (veda) of life (ayur), which has coconut oil as a fundamental ingredient for countless medicinal preparations around 7 thousand years ago, associated with the evolution of the oldest medical knowledge developed in India. It is estimated that $40 \%$ of the medicines available by the pharmaceutical industry were developed from natural sources: $25 \%$ from plants, $13 \%$ from microorganisms and 3\% from animals. Of the 520 new drugs approved by the American Food and Drug Control Agency (FDA), between 1983-1994, 220 (39\%) were developed from natural products. In addition, one third of the most prescribed and sold drugs in the world were developed from natural products. ${ }^{17,18}$ The purpose of this review is to improve knowledge about coconut farming, as well as to synthesize scientific evidence on the biological effects of oil for human health. Therefore, and based on the premise that coconut oil is a by-product derived from coconut, with a high economic and social aggregation value, with biologically proven activity, considering the world scenario that prioritizes sustainability as the basis for conscious development of a society, the present research becomes relevant.

\section{Materials and methods}

The present study was carried out from the elaboration of an integrative literature review, in order to list the bibliography with different methodological approaches on coconut oil and its biological effects for human health. To carry out the review, a guiding methodological course was carried out, consisting of six segments:

1. Identification of the theme,

2. Formulation of the research question that guided the development of the present study,

3. Establishment of criteria for inclusion and exclusion of studies, sampling and search the literature,

4. Definition of the information to be extracted from the selected studies and categorization of the studies;

5. Evaluation of included studies;

6. Interpretation of results, presentation of the review and synthesis of knowledge. ${ }^{19}$

The virtual health library (VHL) and PubMed platforms were used, in view of the time frame from March to October 2020. The search strategies used for the selection of articles occurred by crossing the descriptors in each database: PubMed "MeSH Terms ": coconut and oil AND (Review [ptyp] OR Clinical Trial [ptyp]) AND free full text [sb] AND" last 5 years "[PDat] - articles published between 2015 - 2020, as well as in the VHL: advanced search (tw: (COCONUT)) AND (tw: (OIL)) full texts, with main subject: coconut oil, languages: Portuguese, Spanish and English, publications: last 5 years. The inclusion criteria were scientific articles available on the internet, with free access. As for the type of study, randomized clinical trials and systematic reviews published in full reporting the biological effects of coconut oil in studies with humans were included. Among the highlighted works, those that did not respond to the purpose of this review were excluded, in addition to book 
chapters, manuals, reviews, editorials, reviews, course completion papers, theses, dissertations, papers presented at scientific events and clinical trials on animals or in vitro.

The method used for data extraction was a Table containing:

1. Details of the publication: author and year;

2. Drawing;

3. Intervention and

4. Result.

The primary outcome was to assess the biological effects of coconut oil on human health. All available evidence was summarized and addressed descriptively. The components of the intervention were listed, followed by a narrative synthesis. This included understanding the components of the interventions, exploring the patterns of findings between studies. Finally, the main conclusions of the most robust evidence available were placed in text format, to guide the understanding of the theme and the recommendations of future research. For systematic reviews, the relevant methodological aspects that were assessed were adequate randomization, ensuring allocation secrecy, blinding scheme, analysis by intention to treat and publication bias for better transparency of the reporting of the review process. The final synthesis was presented in a descriptive form, considering the objectives, results and conclusions obtained in each study. The process of identification, selection and inclusion of primary studies took place in stages, as shown in Figure. Initially, 1.036 articles were selected. Of these, 1.019 was excluded in the search for title and abstracts. After examining the full texts, 05 were excluded for not responding to the objectives and 12 were included in this review, according to the selection flow. The excluded articles are due to factors of study limitations, inconsistencies, inaccuracies, guidelines and publication bias (Figure 1).

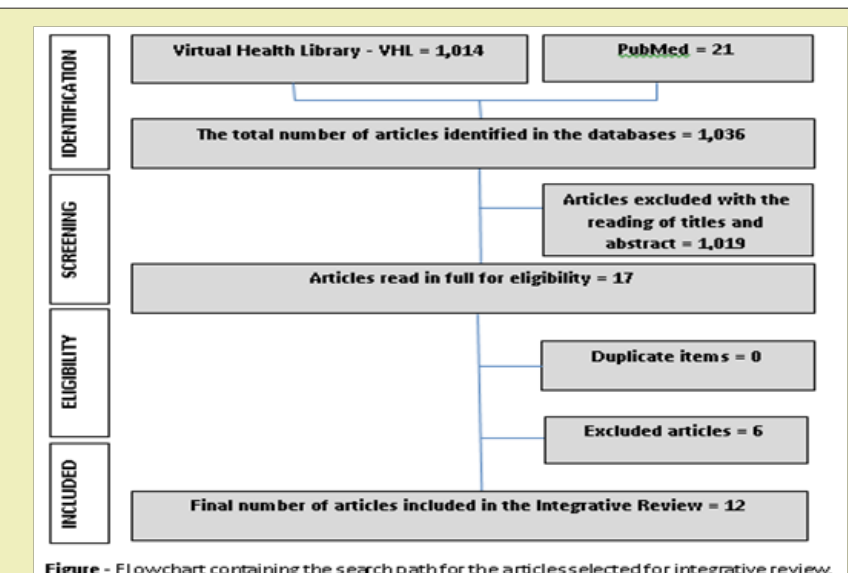

Figure 1: Flowchart containing the path for the articles selected for integrated review.

Table 1: Summary table of the studies included in the review according to the authors, year of publication, quantity and total of the sample, exposure/ intervention and results, 2020

\begin{tabular}{|c|c|c|c|c|}
\hline $\begin{array}{l}\text { Author/ } \\
\text { Year }\end{array}$ & $\begin{array}{l}\text { Out- } \\
\text { lines-ment }\end{array}$ & Sample & Exhibition/Intervention & Result \\
\hline $\begin{array}{l}\text { 1. De La } \\
\text { Rubia Ortiz } \\
\text { et al. }{ }^{24}\end{array}$ & $\begin{array}{c}\text { Clinical } \\
\text { Trial }\end{array}$ & $\begin{array}{l}44 \text { adult indi- } \\
\text { viduals with } \\
\text { Alzheimer's }\end{array}$ & $\begin{array}{l}\text { The intervention group received for } 40 \text { days, } 40 \mathrm{ml} \text { of } \\
\text { coconut oil daily divided between breakfast }(20 \mathrm{ml}) \\
\text { and food }(20 \mathrm{ml}) \text {. Before and after oil administration, } \\
\text { they were assessed using the Mini Mental State cogni- } \\
\text { tive test Examination. }\end{array}$ & $\begin{array}{l}\text { Patients who received oil of coconut showed } \\
\text { statistically significant improvement in the } \\
\text { areas of orientation and construction of the } \\
\text { language. }\end{array}$ \\
\hline $\begin{array}{l}\text { 2. Eyres et } \\
\text { al. }{ }^{25}\end{array}$ & $\begin{array}{l}\text { Systematic } \\
\text { Review }\end{array}$ & $\begin{array}{l}21 \text { works } \\
\text { identified: } \\
8 \text { clinical } \\
\text { trials and } 13 \\
\text { observational } \\
\quad \text { studies }\end{array}$ & $\begin{array}{l}\text { The study examined the effect of coconut oil or other } \\
\text { coconut by-products on the serum lipid profile. }\end{array}$ & $\begin{array}{l}\text { Overall, the weight of evidence from studies } \\
\text { ofintervention until the moment suggests that } \\
\text { the replacementof coconut oil for fats unsatu- } \\
\text { rated fats would alter the blood lipid profile in } \\
\text { a manner consistent with the reduction of risk } \\
\text { factors for diseases cardiovascular diseases. }\end{array}$ \\
\hline $\begin{array}{l}\text { 3. Kay-Tee } \\
\text { Khaw et al. } .^{26}\end{array}$ & $\begin{array}{c}\text { Clinical } \\
\text { Trial }\end{array}$ & $\begin{array}{l}96 \text { partici- } \\
\text { pants random- } \\
\text { ized to one } \\
\text { of the three } \\
\text { interventions }\end{array}$ & $\begin{array}{l}\text { The individuals participating in the research con- } \\
\text { sumed extra virgin coconut oil, extra virgin olive oil } \\
\text { or unsalted butter and were asked to consume } 50 \mathrm{~g} \\
\text { per day of one of these fats for } 4 \text { weeks. }\end{array}$ & $\begin{array}{l}\text { The oil of coconut significantly increased } \\
\text { the levels of HDL-C (cholesterol present in } \\
\text { particles of lipoproteins considered potentially } \\
\text { atherogenic lipoproteins (VLDL, IDL, LDL, } \\
\text { andlipoprotein-A) compared to butter and } \\
\text { olive oil). }\end{array}$ \\
\hline $\begin{array}{l}\text { 4. Borba et } \\
\text { al. }^{27}\end{array}$ & $\begin{array}{c}\text { Clinical } \\
\text { Trial }\end{array}$ & $\begin{array}{l}13 \text { recreation- } \\
\text { al runners } \\
\text { aged } 18 \text { and } \\
40 \text { years }\end{array}$ & $\begin{array}{l}\text { All volunteers performed a } 1600 \mathrm{~m} \text { time trial on a } \\
400 \mathrm{~m} \text { track, each ingesting four different substanc- } \\
\text { es: } 1 \text { ) placebo (water), (2) decaffeinated coffee plus- } \\
\text { CAF isolated (DECAF+CAF), (3) decaffeinated coffee } \\
\text { more CAF isolated more oil from soybeans (DECAF+- } \\
\text { CAF+SO) and (4) coffee decaffeinated more isolated } \\
\text { CAF more oil virgin coconut extra (DECAF+CAF+CO). }\end{array}$ & $\begin{array}{l}\text { Intakeof decaffeinated coffee with the addition } \\
\text { of isolated CAF and extra virgin CO, isolated or } \\
\text { combined, does not improve running times of } \\
1600 \text { and not influence theconcentrations of } \\
\text { EPR and lactate in recreational corridors. }\end{array}$ \\
\hline
\end{tabular}




\begin{tabular}{|c|c|c|c|c|}
\hline $\begin{array}{l}\text { 5. Maki et } \\
\text { al. }^{28}\end{array}$ & $\begin{array}{l}\text { Random- } \\
\text { ized cross- } \\
\text { over study }\end{array}$ & $\begin{array}{l}\text { Men }(\mathrm{n}=12) \\
\text { and women } \\
(\mathrm{n}=13) \text { with } \\
\text { a mean age of } \\
45.2 \text { years }\end{array}$ & $\begin{array}{l}\text { The subjects consumed muffins and rolls providing } 4 \\
\text { tablespoons (g54 g) per day of corn oil or coconut oil } \\
\text { as part of their usual diets for } 4 \text { weeks. }\end{array}$ & $\begin{array}{l}\text { When incorporated into the usual diet, } \\
\text { consumption of foods that provide } 54 \mathrm{~g} \text { of } \\
\text { oil corn produced a profile favorable plasma } \\
\text { lipid of the oil coconut in adults with high } \\
\text { cholesterol. }\end{array}$ \\
\hline $\begin{array}{l}\text { 6.Vijayaku- } \\
\text { mar et al. }{ }^{29}\end{array}$ & $\begin{array}{c}\text { Clinical } \\
\text { Trial }\end{array}$ & $\begin{array}{l}\text { 200individuals } \\
\text { with coronary } \\
\text { atherosclerotic } \\
\text { disease (CAD). }\end{array}$ & $\begin{array}{l}\text { Patients with stable CAD in attendance medical stan- } \\
\text { dard were assigned to receive oilfrom coconut (Group } \\
\text { I) or oil sunflower (Group II) as cooking medium for } \\
2 \text { years. }\end{array}$ & $\begin{array}{l}\text { The oil coconut, although rich in acids fatty } \\
\text { saturated in comparison to oil sunflower, when } \\
\text { used as a means of cooking oil for a period of } \\
2 \text { years did not change standard medical care. } \\
\text { the factors risk cardiovascular and events } \\
\text { Cardiovascular airs related to those lipids who } \\
\text { receive }\end{array}$ \\
\hline $\begin{array}{l}\text { 7.Elson et } \\
\text { al. }^{30}\end{array}$ & $\begin{array}{c}\text { Clinical } \\
\text { Trial }\end{array}$ & $\begin{array}{l}96 \text { children } \\
\text { aged } 6 \text { to } 14 \\
\text { years with at } \\
\text { least one via- } \\
\text { ble flea on the } \\
\text { lower limbs. }\end{array}$ & $\begin{array}{l}\text { An oil mixture of seed of } 20 \% \text { neem ( Azadirachta } \\
\text { indica ) in coconut oil (CN) or with } 0.05 \% \text { potassium } \\
\text { permanganate (KMnO4) to bath feet. }\end{array}$ & $\begin{array}{l}\text { NC was superior in relation to secondary } \\
\text { results of abnormal development and reduced } \\
\text { pathology. There was a greater chance of fleas } \\
\text { quickly grow old in response to NC in compar- } \\
\text { ison to KMnO4. The NC it also reduced acute } \\
\text { pathology and children were more likely to be } \\
\text { pain-free when treated with NC. }\end{array}$ \\
\hline $\begin{array}{l}\text { 8. Schwing- } \\
\text { shacklet al }^{31}\end{array}$ & $\begin{array}{c}\text { Systematic } \\
\text { review }\end{array}$ & $\begin{array}{l}54 \text { clinical } \\
\text { trials }\end{array}$ & $\begin{array}{l}\text { Comparing at least two of the following solid oils/ } \\
\text { fats: saffron, sunflower, rapeseed, hemp, flaxseed, } \\
\text { corn, soybean oil, palm and coconut oil, lard, beef } \\
\text { fat and butter) results in LDL cholesterol (LDL-C), } \\
\text { total cholesterol (CT), HDL cholesterol (HDL-C) and } \\
\text { triacylglycerols (TGs). }\end{array}$ & $\begin{array}{l}\text { The oil palm ( } 74 \% \text { ) showed the highest value } \\
\text { of Sucra for TG and coconut oil ( } 88 \% \text { ) toHDL } \\
\text { C. safflower, sunflower, rapeseed, linseed, corn, } \\
\text { olive, soybean, palm and coconut oil, as well as } \\
\text { fat from beef, were more effective in reducing } \\
\text { LDL-C (- } 0.42 \text { to }-0.23 \text { mmol/l) compared to } \\
\text { butter. }\end{array}$ \\
\hline $\begin{array}{l}\text { 9.Olivei- } \\
\text { ra-de-Lira et } \\
\text { al. }^{32}\end{array}$ & $\begin{array}{c}\text { Clinical } \\
\text { Trial }\end{array}$ & $\begin{array}{l}75 \text { women- } \\
\text { with BMI, 30- } \\
39.9 \mathrm{~kg} / \mathrm{m}^{2}\end{array}$ & $\begin{array}{l}\text { Four groups Found: coconut oil group (COG, } \mathrm{n}=18) \text {, } \\
\text { the safflower oil group (SafG, } \mathrm{n}=19) \text {, Group oil chia } \\
(\mathrm{CH}, \mathrm{n}=19) \text { and the placebo oil of soy }(\mathrm{PG}, \mathrm{n}=19)\end{array}$ & $\begin{array}{l}\text { Coconut oil had a more pronounced effect on } \\
\text { abdominal adiposity and glucose profile. }\end{array}$ \\
\hline $\begin{array}{l}\text { 10.Sciarrillo } \\
\text { et al. }^{20}\end{array}$ & $\begin{array}{c}\text { Clinical } \\
\text { Trial }\end{array}$ & $\begin{array}{l}\text { 10adults }(5 \\
\text { women } / 5 \\
\text { men) }\end{array}$ & $\begin{array}{l}\text { For each meal test, participants }(\mathrm{n}=10 ; 5 \mathrm{M} / 5 \mathrm{~F}) \\
\text { consumed a high fat meal (HFM) }(13 \mathrm{kcal} / \mathrm{kg} ; 61 \% \text { of } \\
\text { the total kcal of fat) with the fat source derived from } \\
\text { butter, oil coconut oil, olive oil or canola oil. }\end{array}$ & $\begin{array}{l}\text { The postprandial triglyceride (TG) responses } \\
\text { to a single HFM composed of different fat } \\
\text { sources did not differ between genders. }\end{array}$ \\
\hline $\begin{array}{l}\text { 12.Lane-Cor- } \\
\text { dovaet al. }{ }^{22}\end{array}$ & $\begin{array}{l}\text { Cross- } \\
\text { over and } \\
\text { randomized } \\
\text { design }\end{array}$ & $\begin{array}{l}11 \text { Individuals } \\
\text { healthy ( } 21 \\
\text { and } 65 \text { years) }\end{array}$ & & $\begin{array}{l}\text { A drink rich in trans fatty acids (AGT) but low } \\
\text { in saturated fatty acids (AGS) and carbo- } \\
\text { hydrates resulted in an acute postprandial } \\
\text { reduction in endothelial function in adults } \\
\text { The drink with a high content of SFA (coconut } \\
\text { oil) demonstratedatendency to reductions in } \\
\text { insulin concentrations. }\end{array}$ \\
\hline
\end{tabular}

Source: elaborated by the authors (2020)

\section{Results}

In the final sample, 12 articles were included in the study, as shown in flowchart. The articles were published in international journals (100\%), with a predominance of the English language (92\%). Regarding the study design, 83.3\% were Clinical Trials and $16.7 \%$ Systematic Reviews (Table 1 ). ${ }^{20-23}$

\section{Discussion}

As described in the Study 1, by De La RubiaOrtiz, et al., ${ }^{24}$ the medium chain triglycerides (TGCM) consisting of medium chain saturated fatty acids (MCFA) as caproic acid, caprylic acid, capric acid and lauric acid as an alternative energy source to glucose, yielding ketone bodies have shown benefits in Alzheimer's patients with varying degrees of dementia. Coconut oil is considered the nutrient with the highest amount of TGCM, since in its composition approximately $90 \%$ are saturated fats, the majority being of medium chain. Among these, lauric acid is the most present (approximately 45\%), although we also find palmitic, stearic, myristic and oleic acids in smaller proportions. This study has limitations regarding the sample size and the treatment period, so it would be necessary to study in depth the results obtained from a larger population, in order to improve the statistical power of the results obtained and over a period of more than one month of intervention to assess in the long term whether the effect obtained is maintained, increased or decreased. It was also possible to analyze that the randomization technique of the clinical trial, allocation secrecy and blinding scheme were not reported. Thus, it's not allowing a satisfactory assessment of the internal validity of the study.

Study 2 by Eyres et al., ${ }^{25}$ which evaluated 21 studies: 8 clinical trials and 13 observational studies, through a systematic review, demonstrated no convincing evidence that the consumption of coconut oil, as opposed to the consumption of unsaturated oils, led to better lipid profiles and a decreased risk of cardiovascular disease (CVD). There was no evidence that coconut oil acted consistently differently from other saturated fats in terms of its effects on blood lipids and lipoproteins. The limitations of the study are pointed out by the flaws in the internalvalidity of the study, thus, the study suggests that other well-designed clinical trials, which include appro- 
priate controls, should be carried out, therefore, the conclusion of this review remains unchanged for clinical decision-making.

Study 3 by Kay-Tee Khaw et al. ${ }^{26}$ which randomized 96 men and women aged 50 to 75 years, with no known history of cancer, cardiovascular disease or diabetes and without the use of lipid-lowering medication and no contraindications to a diet rich in fats, you have chosen to consume one of three dietary fats: virgin coconut oil, extra virgin olive oil or unsalted butter (50 g per day for 4 weeks incorporated into the usual diet) or consume as a supplement. In this study, the levels of LDL (the bad cholesterol) and HDL (the good cholesterol) were raised before the experiment. The results showed no increase in LDL levels, but they also had a significant increase in HDL, the good cholesterol, which was 15\% higher than before for the coconut oil diet. The predominant fatty acids in coconut oil are: lauric acid (C12: 0) and myristic acid (C14: 0) are medium chain fatty acids that are rapidly absorbed by the liver and oxidized to increase energy expenditure, which is a possible explanation for why coconut oil may have different effects compared to other saturated fats. This study by Kay-Tee Khaw et al. ${ }^{26}$ has limitations inherent to the fatty acid clustering convention based only on the number of double bonds. We know that the main groups of fatty acids are associated with different health effects. As yet, the individual fatty acids in each broad classification can have unique biological properties or effects.

It is worth adding, that fatty acids differ worldwide, depending on the predominant food sources of total fats and oils. In view of the critical analysis of the study's evidence, a satisfactory internal validity of the study was possible with adequate randomization, with guaranteed allocation secrecy and adequate blinding scheme. Study 4 by Borba et al., ${ }^{27}$ which randomized 13 runners in order to assess the effect of caffeine (CAF) and extra virgin coconut oil (CO), alone or combined, on running performance in runners, demonstrated that the intake of decaffeinated coffee with the addition of isolated CAF and extra virgin CO, isolated or combined, did not improve the running times of $1600 \mathrm{~m}$, nor did it influence the concentrations of protein electrophoresis (EPR) and lactate in recreational runners.

A recent study by Robinson and colleagues showed that four weeks $(30 \mathrm{~mL} / \mathrm{d})$ of virgin $\mathrm{CO}$ associated with a single cycle of moderate intensity in young adults were able to increase endotheliumdependent dilation of the popliteal artery, but did not change post exercise, or ability antioxidant Total plasma confirming with the study of Borba and reviewers. It was also observed this study Borba et al. ${ }^{27}$ had limitations, due tothe small number of participants, but also, although the temperature and humidity were measured, the wind speed was not measured; so factors suchas these, may have impaired the performance of the race and consequently the results of the study. Already before the methodological aspects, it was observed that the study described: randomization, guarantee the confidentiality of allocation and blinding scheme, thus comprising onesatisfactory internal validity of the study.

Study 5 by Maki et al. ${ }^{28}$ which randomized men $(n=12)$ and women $(\mathrm{n}=13)$ providing 4 tablespoons (g54g) per day of corn oil or coconut oil as part of their usual diets for 4 weeks, demonstrated that, when incorporated into the usual diet, consumption of food that provides 4 tablespoons per day $(\sim 54 \mathrm{~g} / \mathrm{d})$ of corn oil, which contains a greater amount of plant sterols than other cooks and is rich in polyunsaturated fatty acids (PUFAs), HDL cholesterol has not been reduced compared to coconut oil (saturated fatty acids -SFAs) in men and women with above desirable levels of circulating cholesterol. The study has limitations, requiring additional controlled and randomized clinical trials with a larger number of individuals to examine in more detail the potential effects of polyunsaturated fatty acids rich in PUFAs and phytosterol compared to oils rich in SFAs in these parameters. The methodological aspects of the study such as: randomization, guarantee of confidentiality of allocation and blinding scheme were reported, although the external validity of the study is not satisfactory, it showed satisfactory internal validity. Study 6 by Vijayakumar et al., ${ }^{29}$ randomized 200 patients with disease arterial coronary (DAC) stable in care physician pattern. Patients were assigned to receive coconut oil (Group I) or oil of sunflower (Group II) as a means of cooking for 2 years. The oil of coconut, despite the rich in acids fatty saturated in comparison to the oil of sunflower, when used as a means of oil from the kitchen for a period of 2 years does not alter the cardiovascular risk factors and cardiovascular events related to lipids.

The aforementioned study has limitations regarding the number of participants for a dietary intervention. The result may be influenced by the medication being used for CAD. As well, the duration of the dietary intervention may not have been sufficient to elucidate the outcomes of the main cardiac events for the research. Therefore, long-term prospective studies, based on the community/family, in a population with a normal free life, are necessary to respond to the cardiovascular effect of coconut oil. In view of the methodological aspects, it was observed that the study presented randomization, guaranteed allocation secrecy and adequate blinding scheme, demonstrating satisfactory internal validity of the study. Study 7 by Elson et al.,30 to elucidate topical treatment of tungiasis, randomized 96 children aged 6 to 14 years with at least one viable flea on their feet, in which a $20 \%$ neem seed oil mixture was used. (Azadirachta indica) in coconut oil (NC) or with $0.05 \%$ potassium permanganate $\left(\mathrm{KMnO}_{4}\right)$ for foot bath. The results showed that there was a greater chance that fleas would age quickly in response to $\mathrm{NC}$ compared to $\mathrm{KMnO}_{4}$. $\mathrm{NC}$ also reduced the acute pathology associated with tungiasis and children were more likely to be pain-free when treated with NC.

According to Elson et al., ${ }^{30}$ previous studies on tungiasis showed that coconut oil in combination with other plant extracts (jojoba and aloe vera ) had a repellent effect, reducing infections and improving the condition of cases. Other studies in this segment have shown that the fatty acid components of coconut oil have a repellent effect against various hot flies and mosquitoes. In addition, coconut oil can also improve the healing process and affect secondary bacterial infection. The main free fatty acids are from coconut oil, lauric acid metabolising monolaurin and kills bacteria by breaking down the membranes, including species of Staphylococcus, E. coli and Pseudomona. Studies reveal that the oleic acid present in coconut oil increases the permeability of the skin, allowing a better pen- 
etration of the other fatty acids present in coconut oil. In addition, coconut oil increases the speed with which wounds heal and skin repair occurs, through rapid epithelialization, collagen crosslinking, fibroblast proliferation and neovascularization. Other research reveals that virgin coconut oil has also been shown to be effective in preventing and treating atopic dermatitis and xerosis.

Study 7 suggests additional research with a larger sample size to improve the power of the study and even suggests a longer observation period. It was also observed that the methodological aspects that led the clinical trial were well reported. Though the analysis of evidence has been compromised the external validity for clinical application. The study 8 Schwingshackl et al. ${ }^{31}$ who evaluated using a one meta-analysis, 54 trials Clinical that compared at least two of the following oils/solid fats: safflower, sunflower, canola, hemp, flax, corn, olive soy, palm and oil of coconut fat of pig, fat beef and butter showed that the oils high in unsaturated fats, such as safflower, sunflower, rapeseed, linseed, corn, olive, soybean, palm and coconut oil were more effective in reducing the LDL -C in comparison to rich in SFA, as the butter and lard the pig. It was observed in the aforementioned study, the low credibility of the evidence for indirect and moderate comparisons and for mixed/comparisons. To this end, it is necessary that new revisions provide evidence important for the confidence likely and change the estimate of the effect, as acknowledged by the authors. As for internal and external validity of the study, it was observed that it brings a significant number of investigations with inconsistency testing, sensitivity analyzes and judgment of the quality of the evidence. What give you satisfactory internal validity? However, there are negative points to be pointed out, such as: part of the evidence came from indirect comparisons which reveal important heterogeneity and inconsistency. It was also observed that there were similarities between the included studies. Consequently it makes external validity unsatisfactory.

The study 9 by Oliveira-de-Lira and collaborators, ${ }^{32}$ which randomized 75 women - with Body Mass Index (BMI), 30-39.9 for four experimental groups: the coconut oil group ( $\mathrm{CoG}, \mathrm{n}=18$ ), the safflower oil group ( $\mathrm{SafG}, \mathrm{n}=19$ ), the chia oil group (ChG, $\mathrm{n}=19$ ) and the soybean oil placebo group ( $\mathrm{PG}, \mathrm{n}=19$ ) for oil supplementation for 8 weeks. After daily supplementation, different effects were observed depending on supplementation on anthropometric and biochemical parameters. With regard to supplementation with coconut oil, there was a greater adjuvant effect on weight loss, with an emphasis on reducing anthropometric parameters associated with abdominal adiposity. Thus, women supplemented with coconut oil experienced beneficial effects, such as increased HDLc levels and decreased Triglyceride/HDL ratio compared to PG.

The study by Oliveira-de-Lira et al $^{32}$ agree the study by Lipoeto et al. ${ }^{19}$ which demonstrated the absence of harmful effects and increased levels of HDLc in women who took coconut oil supplements. There is epidemiological evidence of populations that consume substantial amounts of coconut oil have no negative effects on cardiovascular health. It was also observed that the study has limitations regarding the number of participants for a dietary in- tervention. However, the methodological aspects that conducted the clinical trial were reported giving it satisfactory internal validity. Study 10 by Sciarrillo et al. ${ }^{20}$ that randomized 10 individuals ( 5 women/5 men - $\mathrm{n}=10$ ) with the objective of determining the postprandial response in triglycerides (TG) to four sources of fat (butter, coconut, olive oil or canola oil) in the adult diet. Participants consumed a high-fat meal (HFM) (13 kcal/kg; $61 \%$ of the total kcal of fat). The results showed that the maximum concentrations of TG after prandial were observed at 2-4 $\mathrm{h}$ after the meal (mean peak between meals: $1.59 \mathrm{mmol} / \mathrm{L}$ ) and suggest that the HFM used in the present study induced a robust postprandial response.

Postprandial lipemia (PPL) is the increase in the TG response in the blood after a meal. Studies show that an altered or reduced ability to eliminate TG in the postprandial period is associated with CVD. ${ }^{21}$ Thus, the study by Sciarrillo et al., ${ }^{20}$ did not corroborate the notion that various sources of fat in the diet result in markedly different PPL responses. However, the study brings strengths in the face of the direct use of mixed HFM in contrast to studies examining PPL from lipid emulsions or lab-derived lipid formulations. As well, it was possible to notice that there was a balanced sample in relation to sex. The limitations can be enumerated by the fact that it only measures blood lipids and glucose. Another limitation is that all participants were young and had few risk factors for CVD. Likewise, the lack of measurement of body composition beyond BMI was another limitation.

It was also observed that the methodological aspects that led the clinical trial by Sciarrillo and collaborators were well reported. It is suggested, then, that future studies may investigate the effects of these various sources of dietary fat on LPP in populations at risk of CVD or with existing CVD. Study 11 by Lyte Gable, Hollis, ${ }^{21}$ with 20 healthy adults who were randomized to a treatment meal and consumed one of the four isoenergetic meals that provided: 1) $20 \%$ fat (control; olive oil) or 35\% fat provided by 2) n-3 ( $\omega 3$ ) (DHA=500 mg; fish oil); 3) n-6 ( $\omega 6$ ) (7.4 g; grape seed oil) or 4) saturated fat (16 g; coconut oil). The primary outcome was defined as the effect of the treatment meal on postprandial endotoxemia. Among the results, it was possible to observe that the n- 6 meal did not present a different result in the postprandial serum endotoxin concentration of the participant of the control meal. Thus, the study concluded that the composition of dietary fat, but not the percentage of calories in the meal, is significant in determining postprandial changes in blood endotoxin concentration in healthy adults in vivo.

Although endotoxemia was associated with low-grade inflammation, there was no increase or decrease in postprandial endotoxemia in this study. To modulate inflammation, it was found that postprandial endotoxemia increased after consuming a meal rich in saturated fatty acids, but decreased after a meal containing polyunsaturated n-3 fatty acids. As well, it points out that the occurrence of inflammation after feeding does not seem to depend on changes in the endotoxin concentrations in the blood, as evidenced by the study. In recent years, accumulated research has shown a link between dietary fat and endogenous endotoxin in relation to metabolic inflammation. Endotoxin, also known as lipopolysaccharide 
(LPS), is considered an important predisposing factor for diseases associated with inflammation, such as atherosclerosis, sepsis, obesity, type 2 diabetes and Alzheimer's. ${ }^{21}$ The study by Lyte, Gable, Hollis ${ }^{21}$ has limitations in view of the number of participants. However, there is good internal validity regarding the methodological criteria used to control the bias of the study. Since the study 12 of Lane-Cordova and collaborators ${ }^{22}$ which randomized 11 individuals healthy for one intervention with beverages of testing with isocaloric loads of fat (520 kcal, $56 \mathrm{~g}$ of fat totalof $5 \mathrm{~g}$ of carbohydrate, $1 \mathrm{~g}$ of protein), with high content of acid fatty trans (TFAs), (42\% from fat overalloil of soybean partially hydrogenated) or acid fatty saturated (SFAs) , (88\% from fat overall - oil of coconut oil) during three visits that occur within the approximately 1 week. The results demonstrated an acute postprandial reduction in endothelial function in healthy adults. In addition, no beverage - rich in trans fatty acids ( AGT) or saturated fatty acids ( AGS) - had any effect on postprandial or carotid aortic stiffness . Some limitations bring the study, before the size of the sample relatively small, although the design of measures random, cross and repeated minimizes the differences between the subjects. It is noted also that no was measured to expansion independently of the endothelium in nitroglycerin sublingual and, therefore, it is possible that the AGT alter the function of vascular smooth muscle brachial artery. However, the study brings one good internal validity as the methodological criteria used to control the biases of the study. As yet, it has one satisfactory validity external and subsidy for new interventions that foster good evidence for practice clinic. Studies indicate that the consumption of a mixed meal with a high content of fat (high in essential fatty acids and carbohydrates) causes transient postprandial endothelial dysfunction of the brachial artery within 3-4 hours. Other studies claim that a diet rich in saturated fatty acids (AGS) and trans fatty acids (AGT) is associated with an increased risk of atherosclerotic cardiovascular disease, mediated in part by the development of dyslipidemia, endothelial dysfunction and/or insulin resistance. ${ }^{23}$ In view of the benefits of coconut oil for human health, reported in this review, other studies have shown that it also promotes an increase in general thermogenesis, beta-oxidation, postprandial thermogenesis, production of CCK (cholecystokinin) and PPY (peptide) and feeling full. It is also capable of inhibiting the reverse transcriptase of HIV (Human Immunodeficiency Virus), preventing the onset of AIDS (Acquired Immunodeficiency Syndrome), and acts as an immunomodulator (lauric acid), contributing to the prevention of autoimmune diseases. ${ }^{24}$

\section{Final considerations}

Taking into account the worldwide recognition of the coconut tree as a vital vegetable resource for all humanity, attributing it the title of palm of greatest economic importance worldwide, both for the social and environmental gains resulting from the sustainable exploitation of culture, as well as also, its biological effects for human health, the study now presented, brings evidence about the benefits, considered significant, of coconut oil in view of the cognitive level of Alzheimer's patients, as well as its consumption, in opposition to the consumption of unsaturated oils which led to better lipid profiles and decreased risk of cardiovascular diseases, as well as a significant increase i1n HDL, the good cholesterol. With regard to supplementation, there was a greater adjuvant effect on weight loss, with an emphasis on reducing anthropometric parameters associated with abdominal adiposity. The gaps in the studies analyzed are related to biases, be they for publication or for being primary studies, in addition to difficulties in combining these studies due to differences in populations, interventions, comparators and definition of outcomes by clinical heterogeneity. Findings that make the internal and external validity of some studies unsatisfactory in view of the critical analysis of the evidence so, this review answered the research question, and expanded existing knowledge on the biological effects of the coconut oil by-product for human health. It is recommended that studies with different interventions and clinical homogeneity be brought together for the most in-depth critical assessment and synthesis of the best evidence.

\section{Acknowledgments}

None.

\section{Funding}

None.

\section{Conflicts of interest}

Author declares that there is no conflict of interest.

\section{References}

1. Alves KNA et al. Study of the evolution of coconut cultivation in municipalities of state of pará and in the main brazilian producing states. Magazine Agroecosystems. 2018;10(2):209-224.

2. Castro CP, Passos EEM, Aragão WM. The phenology of dwarf coconut cultivars in north of sergipe coastal tablelands. Rev Bras Frutic Jaboticabal. 2009;31(1).

3. Farias Neto JT, Paulo Manoel Pontes Lins, Marcos Deon Vilela de Resende, et al. Genetic Selection in Coconut Hybrid Progenies. Revista Brasileira de Fruticultura. 2009;31(1):190-196.

4. Martins CR, Jesus Júnior LA. Evolution of coconut production in Brazil and international trade. (Documents 164) Embrapa Tabuleiros Costeiros, Aracaju. 2011.

5. Foale M, Harries H. Farm and Forestry Production and Marketing Profile for Coconut (Cocos nucifera). In: Elevitch CR, editor. Specialty crops for pacific island agroforestry, Holualoa, Hawai'i: Permanent Agriculture Resources (PAR). 2009.

6. Martins CR, Jesus Júnior LA. Production and commercialization of coconut in Brazil against internationaltrade: panorama 2014.

7. Brainer MSCP. Coconut production: the northeast is a national highlight. Technical Office of Economic Studies of the Northeast-ETENE. 2018.

8. Silva AC. Reuse of green coconut shell. Environmental Monographs Magazine. REMOA. 2014;13(5):4077-4086.

9. Cavalcante LV. The new geography of coconut production in Brazil. In: XI ANPEGE NATIONAL MEETING. São Paulo. Annals. Mato Grosso do Sul: Editora UFGD. 2015. p. 2709-2720.

10. Sampaio I, Ferreira S, Juiz P. Prospective Study Relating to the Use of CoconutFruit as a Raw Material for Cosmetics Manufacturing. Prospecting Notebooks-Salvador. 2019;12(2):314-326.

11. Aragão WM, Ribeiro MMFV. Coconut cultivars for the production of dry coconut: Giant coconut vs hybrids. In: Cintra FLD, Fontes HR, Passos EEM, Ferreira JMS, editors. Technological foundations for the revitalization of areas cultivated with giant coconut trees in northeastern Brazil. Aracaju: Embrapa Tabuleiros Costeiros; 2009. p. 37-60, 232.

12. Siqueira LA, Aragão WM, Tupinambá EA. The introduction of the coconut tree in Brazil: historical and agronomic importance. Embrapa Tabuleiros Costeiros. 2002.

13. Brazil. DRAFT LAW No. 10,788-A. Institutes the National Policy to 
Encourage Quality Coconut Culture. Coordination of Permanent Commissions-DECOM-P_6914. 2018.

14. Almeida LCT. Antimicrobial potential of coconut oil in wound treatment. Rev Rene. 2012;13(4):880-887.

15. Arlee R, Suanphairoch S, Pakdeechanuan P. Difference's inchemical components and substances related to antioxidants in virgin coconut oil from coconut hybrids and their parents. Int Food Res. 2013;20:2103-2109.

16. Calixto JB. Biodiversity as a source of medicines. Cienc Worship. 2003;55(3):37-39.

17. Ayurveda. Florida: Wikimedia Foundation; 2020.

18. Mendes KDS, Silveira RCCP, Galvão CM. Integrative review: research method for incorporating evidence in health and nursing. Text Contexto Enferm. 2008;17(4):758-764.

19. Nur I Lipoeto, Zulkarnain Agus, Fadil Oenzil, et al. Dietary intake and the risk of coronary heart disease among the coconut-consuming Minangkabau in West Sumatra, Indonesia. Asia Pac J Clin Nutr. 2004;13:377-384.

20. Christina M Sciarrillo, Nicholas A Koemel, Patrick M Tomko, et al. Postprandial Lipemic Responses to Various Sourcesof Saturated and Monounsaturated Fat in Adults. Nutrients. 2019;11(1089):1-15.

21. Lyte JM, Gabler NK, Hollis JH. Postprandial serum endotoxin in healthy humans is modulated by dietary fat in a randomized, controlled, crossover study. Lipids in Health and Disease. 2016;14(186).

22. Abbi D Lane-Cordova, Jordan R Witmer, Kaitlyn Dubishar, et al. High trans but not saturated fat beverage causes an acute reduction in postprandial vascular endothelial function but not arterial stiffness in humans. Vascular Medicine. 2016;21(5):429-436.

23. Ribeiro LGT. The scientific truth about a functional superfood called coconut oil. Braz J Surg Clin Res. 2017;18(3):109-117.

24. José Enrique De la Rubia Ortí, Carmen Sánchez Álvarez, Pablo Selvi Sabater, et al. How does coconut oil affect cognitive performance in alzheimer patients? Nutr Hosp Madrid. 2017;34(2):352-356.

25. Laurence Eyres, Michael F Eyres, Alexandra Chisholm, et al. Coconut oil consumption and cardiovascular risk factors in humans. Nutrition Reviews VR. 2016;74(4):267-280.
26. Kay-Tee Khaw, Stephen J Sharp, Leila Finikarides, et al. Randomized trial of coconut oil, olive oil or butter on blood lipids and other cardiovascular risk factors in healthy men and women. BMJ Open. 2018;8(02016):1-14.

27. Gabrielle de Lima Borba, Julianne Soares de Freitas Batista, Ludmilla Marques Queiroz Novais, et al. Acute Caffeine and Coconut Oil Intake, Isolated or Combined, Does Not Improve Running Times of Recreational Runners: A Randomized, Placebo- Controlled and Crossover Study. Nutrients. 2019;11(1661):1-9.

28. Kevin C Maki, Wendy Hasse, Mary R Dicklin, et al. Corn Oil Lowers Plasma Cholesterol Compared with Coconut Oil in Adults with Above-Desirable Levels of Cholesterol in a Randomized Crossover Trial. The Journal of Nutrition. 2018;148(10):1556-1563.

29. Maniyal Vijayakumar, DM Vasudevan, KR Sundaram, et al. A randomized study of coconut oil versus sunflower oil on cardiovascular risk factors in patients with stable coronary heart disease. Indian Heart Journal. 2016;68:498-506.

30. Lynne Elson, Kithi Randu, Hermann Feldmeier, et al. Efficacy of a mixture of neem seed oil (Azadirachta indica) and coconut oil (Cocos nucifera) for topical treatment of tungiasis. A randomized controlled, proof-ofprinciple study. PLOS Neglected Tropical Diseases. 2019;13(11):1-19.

31. Lukas Schwingshackl, Berit Bogensberger, Aleksander Benčič, et al. Effects of oils and solid fats on blood lipids: a systematic review and network meta-analysis. Journal of Lipid Research. 2018;59:1771-1782.

32. Luciene Oliveira-de-Lira, Eduila Maria Couto Santos, Raphael Fabrício de Souza, et al. Supplementation-Dependent Effects of Vegetable Oils with Varying Fatty Acid Compositions on Anthropometric and Biochemical Parameters in Obese Women. Nutrients. 2018;10(932):1-14.

33. Susan A Robinson, Myles W O’Brien, Scott A Grandy, et al. Short-term supplement of virgin coconut oil improves endothelial-dependent dilation but not exercise-mediated hyperemia in young adults. Nutr Res. 2019;67:17-26. 